CASSOWARY Volume 2(2): 147 - 161

ISSN : 2614-8900

E-ISSN : 2622-6545

CProgram Pascasarjana Universitas Papua, https://pasca.unipa.ac.id/

\title{
Evaluasi dan re-disain tipologi ruang terbuka hijau (kasus daerah perkotaan di Provinsi Papua Barat)
}

\author{
Evaluation and re-design of green open space typologies (case of urban areas in West \\ Papua Province)
}

Marlina Rumiris*, Roni Bawole dan Thomas Pattiasina

Program Studi S2 Ilmu Lingkungan, Program Pascasarjana, Universitas Papua Jalan Gunung Salju, Amban, Manokwari, Kodepos 98314, Papua Barat, Indonesia

*Email: rumiris.m.w@gmail.com

\begin{abstract}
In general, the presence of green open space as one element in the urban spatial is very weak and the potencial is reduced portion because they do not have a high economic value. One function of green open space is for micro-climate amelioration, making green open space as a lugs of the city for helping the formation of a cool and comfortable climate in the vicinity. This comfort is determined by the interdependence between the factors of air temperature, air humidity, light and wind movement. Vegetation can improve the quality of the local climate or reducing temperature named micro-climate amelioration function as well. This study aimed to evaluate and redesign the typology of green open space to create green resolution with conversion of carbon to compansate for changes in the landscape that occur as a result of ongoing development. The study was conducted in urban areas of West Papua Province with five cases were selected purposively. Refers to the Ministry of Public Work No. 5 of 2008 and some related references, the results of research (qualitative exploration research) showed that 3 of the 5 cases have not met the ideal typology of Green Open Spaces, while two other cases have met the ideal typology for ecological function, but remain in need of the final material. Redesigns of Green Open Spaces that has been generated from this study are expected to restore ecological functions with holding the ecologycal aspect as a priority matter to consider as well. Therefor those can be used by local goverments for planning repairs or improvements in the future.
\end{abstract}

Keywords: Green Open Space, Amelioration of Micro-Climate, Green Resolutions.

ABSTRAK: Secara umum, keberadaan ruang terbuka hijau sebagai salah satu elemen dalam tata ruang kota sangat lemah dan potensinya berkurang karena tidak memiliki nilai ekonomi yang tinggi. Salah satu fungsi ruang terbuka hijau adalah untuk perbaikan iklim mikro, menjadikan ruang terbuka hijau sebagai lug kota untuk membantu pembentukan iklim yang sejuk dan nyaman di sekitarnya. Kenyamanan ini ditentukan oleh saling ketergantungan antara faktor-faktor suhu udara, kelembaban udara, cahaya dan pergerakan angin. Vegetasi dapat meningkatkan kualitas iklim lokal atau mengurangi suhu yang disebut fungsi perbaikan iklim-mikro. Penelitian ini bertujuan untuk mengevaluasi dan mendesain ulang tipologi ruang terbuka hijau untuk membuat resolusi hijau dengan konversi karbon sebagai pendamping untuk perubahan lanskap yang terjadi sebagai 
akibat dari pembangunan berkelanjutan. Penelitian dilakukan di daerah perkotaan di Provinsi Papua Barat dengan lima kasus dipilih secara purposive. Mengacu pada Kementerian Pekerjaan Umum No. 5 tahun 2008 dan beberapa referensi terkait, hasil penelitian (riset eksplorasi kualitatif) menunjukkan bahwa 3 dari 5 kasus belum memenuhi tipologi ideal Ruang Terbuka Hijau, sementara dua kasus lainnya telah memenuhi tipologi ideal untuk fungsi ekologis, tetapi tetap membutuhkan bahan final. Redesain Ruang Terbuka Hijau yang telah dihasilkan dari penelitian ini diharapkan dapat mengembalikan fungsi ekologis dengan memegang aspek ekologis sebagai hal prioritas untuk dipertimbangkan juga. Untuk itu hal tersebut dapat digunakan oleh pemerintah daerah untuk merencanakan perbaikan atau peningkatan di masa depan.

Kata kunci: Ruang Terbuka Hijau, Ameliorasi Iklim Mikro, Resolusi Hijau.

\section{PENDAHULUAN}

Keberadaan RTH merupakan salah satu unsur dalam tata ruang kota yang sangat lemah dan paling potensial berkurang porsinya karena dianggap tidak memiliki nilai ekonomis yang tinggi. Padahal sesungguhnya, nilai manfaat yang kita terima akan keberadaan RTH adalah nilai ekonomi yang termaktub secara tidak langsung (intangible impact) pada nilai kesehatan, nilai budaya yang menjadi jati diri daerahnya, nilai investasi jangka panjang pada kualitas dan kuantitas hidrologi, udara dan sebagainya. Penggunaan lahan untuk kepentingan komersil telah mengalahkan kepentingan ekologis. Pembangunan dengan menggunakan lahan/kavling secara maksimal, akan mengurangi daya serap air ke dalam tanah. Keadaan ini menyisakan kesan gersang, berkurangnya hamparan hijau, peningkatan suhu atau udara yang makin panas, gerah dan sangat berdebu.

Salah satu fungsi RTH adalah untuk ameliorasi iklim mikro, menjadikan RTH sebagai paru-paru kota untuk membantu pembentukan iklim yang sejuk dan nyaman di sekitarnya. Kenyamanan ini ditentukan oleh adanya saling ke-terkaitan antara faktor-faktor suhu udara, kelembaban udara, cahaya dan pergera-kan angin. Didukung dengan hasil pene-litian di Jakarta, membuktikan bahwa suhu di sekitar kawasan RTH (di bawah pohon teduh), dibanding dengan suhu di luarnya, bisa mencapai perbedaan angka $2-4^{\circ} \mathrm{C}$ (Adisasmito, 2008). Pembuktian bahwa tumbuhan dapat efektif membentuk udara bersih dapat dicermati dari hasil studi penelitian Bernatzky yang menyatakan bahwa setiap 1 hektar RTH yang ditanami pepohonan, perdu, semak dan penutup tanah, dengan jumlah permukaan daun seluas 5 hektar maka sekitar 900kg $\mathrm{CO}_{2}$ akan dihisap dari udara dan melepaskan sekitar $600 \mathrm{~kg} \mathrm{O}_{2}$ dalam waktu 12 jam (Moniaga, 2008). Vegetasi dapat memperbaiki kualitas iklim lokal atau penuruhan suhu yang disebut fungsi ameliorasi iklim mikro. Suhu udara dapat diturunkan $5,5^{\circ} \mathrm{C}$ $11^{\circ} \mathrm{C}$ ketika temperatur rata-rata udara $32^{\circ} \mathrm{C}$ dan ketika temperature rata-rata $21^{\circ} \mathrm{C}$ dapat turun $2,5^{\circ} \mathrm{C}-5,5^{\circ} \mathrm{C}$. Hutan lebat dapat me-nangkap $80 \%$ radiasi matahari melalui daun, cabang dan ranting pepohonan dan mencapai tanah bisa kurang dari 5\% se-panjang hari. Permukaan berumput lebih dingin 33\% daripada paving, karena rum-put dapat menjaga agar suhu konstan, se-dangkan paving dapat memantulkan pa-nas (Direktorat Penataan Bangunan dan Lingkungan, 2012).

Berdasarkan pada keadaan di atas, penyediaan RTH itu sangat penting 
dan perlu ditingkatkan kualitas dan kuan-titasnya. Oleh sebab itu diperlukan kebi-jakan pemerintah dalam alokasi lahan yang legal, pasti dan terencana untuk mewujudkan RTH dalam setiap lahan/kawasan/wilayah yang terbangun. Di samping itu diperlukan keseragaman paradigma penyediaan ruang terbuka yang berfungsi ekologi. Pasal 29 ayat 2 Un-dang-Undang No.26 Tahun 2007, meng-amanatkan bahwa 'proporsi ruang terbu-ka hijau pada wilayah kota paling sedikit 30 (tiga puluh) persen dari luas wilayah kota, proporsi ruang te-rbuka hijau publik pada wilayah kota paling sedikit 20 (dua puluh) persen da-ri luas wilayah kota' dan pasal 30 bahwa 'ketentuan lebih lanjut mengenai penyediaan dan pemanfaatan ruang terbuka hijau dan ruang terbuka nonhijau sebagaimana dimaksud dalam Pasal 28 huruf $a$ dan huruf $b$ diatur dengan Peraturan Menteri'. Menindaklanjuti amanah dalam Undang-Undang tersebut maka Kementerian Pekerjaan Umum me-nerbitkan Peraturan Menteri Pekerjaan Umum No.5/PRT/M/2008 tentang Pedoman Penyediaan Ruang Terbuka Hijau di Perkotaan.

Kecenderungan pembangunan kota dan kota yang mulai berkembang, pada umumnya dengan pendekatan ekonomi. Pembangunan yang sedang blooming (termasuk di Provinsi Papua Barat), khususnya sektor perumahan dan pertokoan/ruko, kawasan perkantoran, masih memberikan pemandangan warna hijau dan segar. Namun secara visual, setiap lahan perumahan yang dipakai banyak menghabiskan lahan dan hanya menyisakan sedikit areal untuk ruang hijau yang berfungsi ekologis. Walaupun peraturan penggunaan lahan dalam konteks Koefisien Dasar Bangunan (KDB) dan Koefisien Lantai Bangunan (KLB) sudah mengaturnya, penggunaan lahan skala kawasan; misalnya pada sektor perumahan oleh pihak pengem- bang masih diragukan. Idealnya, setiap kawasan menyisakan porsi lahan minimal 20\% untuk penyediaan Ruang Terbuka Hijau publik dan $10 \%$ yang bersifat privat. Kondisi ini telah menimbulkan kerusakan tidak hanya pada sumberdaya alam tetapi juga pada penurunan derajat kesehatan manusia. Terjadinya fenomena pemanasan bumi, degradasi kualitas lingkungan dan bencana lingkungan (seperti banjir) telah membangkitkan kesadaran dan tindakan bersama akan pentingnya menjaga keberlanjutan air bersih dan udara sehat di kota, untuk menjamin kelangsungan dan kelayakan kehidupan umat manusia di muka bumi.

Tujuan umum penelitian ini adalah mengevaluasi bentuk dan efektifitas fungsi Ruang Terbuka Hijau daerah perkotaan di Provinsi Papua Barat. Secara khusus penelitian ini bertujuan untuk memberikan hasil evaluasi dalam bentuk redisain (mendisain ulang) $\mathrm{RTH}$ dengan gagasan pemikiran eksploratifkualitatif. Dari sisi ilmu lingkungan, beberapa aspek yang ditinjau (aspek tata ruang/spasial, aspek ekologi, aspek estetika dan aspek sosial-ekonomi-budaya), maka penelitian ini menjadi perlu untuk dilaksanakan. Setelah memadukannya dengan ilmu arsitektur (aspek struktur/kekokohan, aspek estetika dan aspek fungsi) maka kemudian dilakukan re-disain untuk pembenahan. Penelitian ini juga akan membuka kemungkinan akan diadakannya penelitian lebih lanjut yang berkaitan dengan RTH.

\section{METODE PENELITIAN}

Penelitian ini dilaksanakan pada beberapa tempat/lokasi yang dipilih secara purposive atau sengaja; dimana dasar pemilihan memprioritaskan tipologi penyediaan RTH yang pernah mendapat dana stimulus dari pusat. Tetapi tidak menutup kemungkinan mengang- 
kat studi RTH yang non-stimulus. Evaluasi RTH nonstimulus yang dipilih adalah Taman Isak Kijne di Kabupaten Manokwari karena memiliki sebuah alasan visual yang berkesan dengan adanya patung yang memaknai pemberian berkat. RTH yang mendapat dana stimulus adalah RTH Perumahan Bumi Marina Kabupaten Manokwari (penyediaan fasilitas bermain anak), RTH depan Kawasan Bandara Kota Sorong (pendanaan perencanaan dan fisik tahap-1), RTH Perkantoran Bupati Waisai Kabupaten Raja Ampat (pendanaan fisik lapangan upacara) dan RTH di Perkantoran Arfai Kabupaten Manokwari (pendanaan perencanaan dan penyediaan fisik RTH). Penelitian ini berlangsung selama tiga bulan (dari bulan Agustus - Oktober 2014).

Peneliti menggunakan program disain bidang arsitektur (seperti sktechup) dan program pendukung sejenis yang terkait dalam proses modelling sebagai hasil review konsep dan re-disain RTH yang sudah dievaluasi.

Penelitian ini merupakan penelitian eksploratif - kualitatif dengan metode observasi dan wawancara dipadu dengan pendekatan kepustakaan. Observasi dilakukan pada objek RTH yang diamati pada hari dan waktu secara berkala dengan pengulangan $1 \mathrm{x}$ seminggu dalam masa pengamatan dan evaluasi. Kegiatan wawancara dilakukan dengan teknik open-ended question, di mana pertanyaan berpeluang akan berkembang dari jawaban.

Seperti dikemukakan oleh Sukandar rumidi (2002) bahwa penelitian eksploratori ini dilakukan dengan cara:

1. Survey pustaka yaitu dengan mempelajari bahan tertulis antara lain jur-nal atau kumpulan seminar RTH, studi literatur atau acuan normatif.

2. Survey pengalaman yaitu dengan mencari informasi dari orang yang menjadi pengguna dengan teknik interview. Peneliti melakukan wawancara terhadap orang yang tinggal di sekitar objek dan yang dari pengguna luar.

3. Studi observasi yang dilakukan secara berkala dan wawancara dilakukan terhadap pengguna langsung dan pengguna tidak langsung (dari luar)

Variabel yang diamati dan dievaluasi adalah:

1. Aspek tata ruang (secara spasial) yai-tu jarak tempuh dan lokasi, menyangkut pola sifat lingkungan (lingkungan padat, kurang padat, tidak padat),

2. Aspek ekologi yaitu menyangkut hu-bungan antara RTH dan manusia yang berada di kawasan bersangkutan, yang dapat dijabarkan ke dalam kemampuan tanah untuk menyerap dan menyimpan air maupun suplai oksigen guna memenuhi kebutuhan manusia di atasnya.

3. Aspek estetika, yaitu jenis vegetasi dan penempatannya satu terhadap lainnya,

4. Aspek sosial menyangkut fungsi sosial, ekonomi dan budaya

Menurut Amirin (2009), dalam analisis data kualitatif, data dikelompokkan berdasarkan sumbernya yaitu masyarakat, stake-holder dan dari pihak swasta/pe-ngembang. Tahapan yang dilakukan ada-lah:

1. Pengelompokan/inventarisir data yang diperoleh,

2. Mengidentifikasi masalah atau keku-rangan dari RTH yang ada,

3. Re-konsep secara 2 (dua) dimensi.

Sama dengan pendekatan analisis data kualitatif, tahapan yang digunakan dalam (EDA) Exploratory Data Analisis adalah dengan urutan:

1. Masalah dikelompokkan dari perolehan data, 
2. Analisis masalah dan kekurangan yang ada pada objek penelitian,

3. Re-konsep secara 2 (dua dimensi)

4. Modeling dengan program sketchup dan program sejenisnya.

\section{HASIL DAN PEMBAHASAN}

\section{RTH Taman Isak Kijne, Manok- wari}

\subsection{Gambaran Kondisi eksisting}

Taman Isak Kijne berada pada persimpangan jalan, tepatnya pada perti-gaan jalan menuju Arfai dan Bandara Rendani. Dengan luasan \pm $1200 \mathrm{~m}^{2}$ maka RTH ini masuk kategori Kawasan Hijau Binaan, dengan tipologi 'taman kota' menonjolkan nilai estetikanya, untuk kesan pandang keindahan kota kecil. Tidak ada bangunan yang permanen kecuali patung besar, pot-pot bunga, air mancur, pohon ketapang 2 buah dan 2 rumpun bambu hias serta tiang 'traffic light' dan beberapa tanaman hias/perdu.

\subsection{Evaluasi Aspek Kelayakan RTH}

Hasil pengamatan diuraikan dalam aspek-aspek berikut ini:

a. Dari aspek tata ruang, taman segitiga ini terbentuk secara natural karena berada pada pertigaan persimpangan jalan kelas arteri. Taman berada pada lingkungan yang tidak terlalu padat, lingkungan sekitarnya adalah rumah-rumah, perkantoran dan kantor unit bank. Selain untuk memberikan ke-mudahan lintas pandang pada pe-ngendara yang lalu lalang tetapi juga memberikan porsi fungsi penghias kota pada lingkungan sekitarnya. Koefisien Dasar Bangunan (KDB) yang terpakai sekitar 60\% perkerasan (con-cretebased), sisanya adalah hijau rumput.

b. Dari aspek ekologi, secara topografi, lokasi taman relatif lebih rendah dari jalan, sehingga memudahkan pengli-hatan dari arah sekitarnya (dari tiga penjuru jalan). Namun dari fungsi ekologisnya, taman ini lebih banyak menggunakan material perkerasan (concrete-based/hard land scaping material) sehingga mengurangi daya serap air ke dalam tanah. Lahan segitiga taman ini berfungsi sebagai taman kota, selain terdapat patung besar juga diisi elemen pot-pot kecil yang banyak berbentuk lingkaran dan kotak, membuat taman ini akan lebih berfungsi pada aspek non-ekologis, dengan memberi manfaat tidak langsung (sosial-estetika) kepada masyarakat sekitar dan penikmat dari luar. Taman ini dapat dinikmati keind-hannya dan untuk saat tententu, beberapa orang terkadang menikmati tempat itu sebagai tempat istirahat anak-anak dan pekerja tukang di sore hari (hanya duduk saja). Di dalam taman terdapat dua buah pohon ketapang yang berada pada titik sembarangan. Banyaknya pot tidak semua diisi tanaman hias, kemungkinan sudah ditanam tetapi mati dan tidak diganti lagi. Hal lain yang diperkirakan adalah tidak ada penggantian tanah dalam pot-pot secara berkala sehingga tanaman hias menjadi mati.

c. Dari aspek estetika, sedianya taman ini memberikan manfaat estetika yang baik, namun taman ini belum mendapatkan perhatian terutama dalam pengelolaan dan perawatan yang rutin, hanya saat tertentu apabila ada kegiatan daerah yang menginstruk-sikan kebersihan kota keseluruhan. Banyaknya elemen pot bunga yang kecil-kecil membuat jenis vegetasi kurang diperhatikan keragamannya dan kemudahan perawatannya terutama bila tanah dalam pot tidak diganti secara 
berkala. Keberadaan pot-pot bunga yang kecil dan areal perkerasan, membuat habisnya ruang untuk resapan air ke dalam tanah. Penempatan jenis pohon peneduh pada dua titik yang sembarangan, akan mengurangi tujuan pandangan pada patung besar yang menjadi pusat elemen di taman.

d. Dari aspek sosial, ekonomi dan budaya; Taman ini tidak mempengaruhi pergerakan ekonomi yang signifikan pada masyarakat sekitar kerana tidak ada kegiatan ekonomi yang terjadi di dalam taman (tidak ada yang berjualan). Elemen Patung Isak Kijne mendominasi taman ini sebagai penanda untuk dikenang (dari aspek budaya) atau menjadi pengingat jejak sejarah peradaban bagi kota Manokwari. Arus kendaraan yang menuju Bandara atau yang akan meninggalkan kota Manokwari; jika sekilas melihat ke arah taman, Patung Isak Kijne memberi makna tersendiri yaitu seolah tengah memberkati orang yang hendak bepergian meninggalkan kota Manokwari.

\subsection{Implementasi arahan dan konsep redisain Taman Isak Kijne}

Di bawah ini (Gambar.1 kiri) disertakan sketsa layout Taman Isak Kijne sebelum dan setelah re-disain untuk menunjukkan hal-hal apa yang kurang pada kondisi eksisting dan apa yang dirubah dan dilengkapi pada hasil re-disain taman. Situasi taman saat ini adalah:

a. Adanya elemen patung yang menjadi 'center point' dan bermakna historis.

b. Sepanjang sisi luar dibuat material 'paving-block' tetapi kenyataannya tidak terpakai sehingga kurang efektif sebagai pedestrian.

c. Elemen pot-pot kecil bentuk bulat dan kotak, ditanami bunga-bunga dengan jenis yang berbeda-beda sehingga kurang keseragaman, terkesan tidak terawat kemungkinan tidak ada penggantian media tanah secara ber-kala.

d. Elemen air mancur pada ujung lahan, tidak terpakai.

e. Sisa lahan ditumbuhi rumput liar dan terdapat dua buah pohon ketapang yang tumbuh di ujung dan sisi belakang lahan.

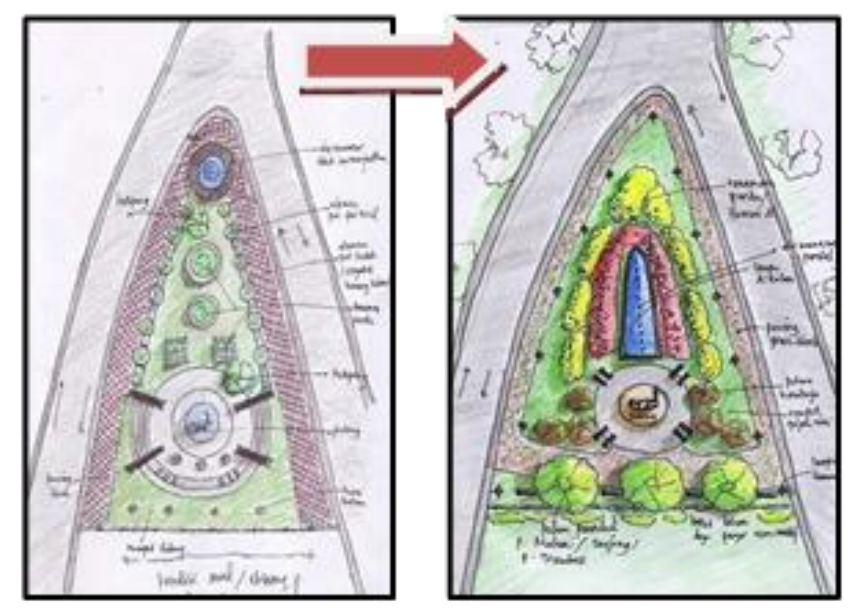

Gambar 1. Layout sebelum redisain (kiri) dan layout setelah redisain (kanan).

Redisain taman (Gambar.1. kanan) me-nunjukkan perubahan berikut: a. Elemen patung dipertahankan dengan penambahan Pohon Kamboja atau Pohon Dadap Merah yang me- 
ngundang datangnya burung-burung kecil disekitarnya (masing-masing tiga pohon di sebelah kiri dan kanan),

b. Tiga abuah pohon peneduh potensi mengkonversi karbon (seperti: Tanjung, Mahoni, Kiara Payung atau sejenisnya) sebagai latar belakang patung dilengkapi asesoris taman yaitu bangku taman,

c. Penambahan vegetasi jenis 'pembatas' sebagai dinding-hijau taman,

d. Penggantian material 'pavingblock' menjadi 'grass-block' untuk memberi kesan hijau rumput dan dapat menye-rap air ke dalam tanah,

e. Air mancur dialokasikan ke bagian tengah dengan tipe 'dancing-waterfall',

f. Tanaman perdu yang berwarna warni untuk estetika taman,

g. Lampu taman yang pendek di sepanjang sisi luar,

h. Sisa lahan ditanami rumput hias untuk taman.

Konsep perubahan demikian dapat memberi nuansa baru RTH Taman Isak Kijne, lebih berfungsi ekologis dan indah tanpa menghilangkan fungsi estetika patung dan taman serta pemeliharaannya diharapkan lebih mudah karena tidak perlu lagi harus mengganti tanah dalam pot-pot secara berkala (Gambar.2)

\section{RTH Kompleks Perumahan Bumi Marina, Manokwari \\ 2.1.Gambaran Kondisi Eksisting}

Kompleks Bumi Marina merupakan perumahan yang dikerjakan oleh pengembang. Luas areal sekitar $18 \mathrm{Ha}$. Penghuni Perumahan Bumi Marina seki-tar 408 KK (Kepala Keluarga), terdapat 6-RT dan 1-RW. Eksistensi Ruang Ter-buka Hijau yang ada dalam kompleks terbagi dua: yaitu bersifat publik (lapangan yang luas di depan akses masuk) dan yang bersifat privat (taman buah dan pohon milik pribadi). Terdapat beberapa sudut kavling pada blok-blok rumah, seperti tanah yang tersisa, kemungkinan diperuntukkan untuk taman bermain tetapi kondisinya masih tidak terpakai (lahan kosong). Luas lapangan Bumi Marina adalah sekitar $6.480 \mathrm{~m}^{2}$ (ukuran $144 \mathrm{~m} \times$ x $45 \mathrm{~m}$ ). Sisa lahan kosong pada ujung blok-blok rumah memiliki luas sekitar $60 \mathrm{~m}^{2}$ (ukuran $5 \mathrm{~m}$ x 12m).

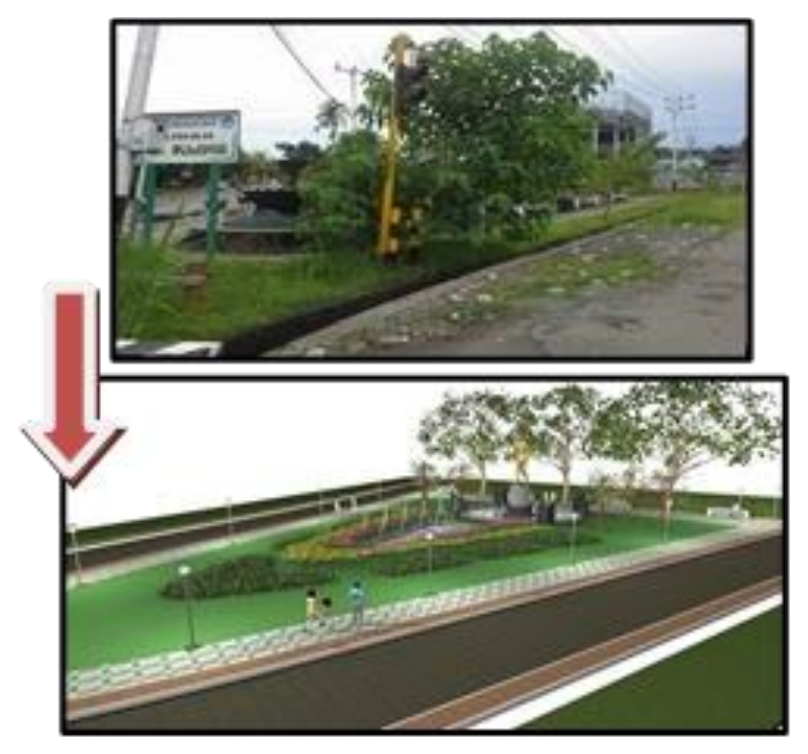

Gambar 2. Situasi awal taman (atas) dan situasi redisain taman (bawah). 
CASSOWARY Volume 2 (2): 147 - 161

ISSN : 2614-8900

E-ISSN : 2622-6545

CProgram Pascasarjana Universitas Papua, https://pasca.unipa.ac.id/

\subsection{Evaluasi Aspek Kelayakan RTH}

a. Dari aspek tata ruang (spasial ruang), kompleks perumahan Bumi Marina seluas \pm 18 ha, idealnya pengembang properti menyisakan minimal 20\% lahan RTH privat kawasan (sekitar 3,6 hektar) yang terdistribusi atau tersebar secara merata/adil. Dalam Peraturan Menteri Pekerjaan Umum No.5/PRT/M/ 2008, bahwa untuk permukiman dengan jumlah jiwa 250 hingga 2500 jiwa, harus menyediakan beberapa RTH tipe taman RT dan taman RW; dengan luas minimal $250 \mathrm{~m}^{2}$ (untuk 250 jiwa) dan $1.250 \mathrm{~m}^{2}$ (untuk 2500 jiwa) yang disebar atau ditempatkan di tengah lingkungan RT dan di pusat kegiatan RW dan memiliki radius capaian 300m dari rumah-rumah penduduk yang dilayani. Kenyataannya tidak terdapat sebaran RTH pada blokblok rumah, tetapi hanya terkonsentrasi pada lapangan besar (Luas $\pm 6.480 \mathrm{~m}^{2}$, tidak sampai 1ha) pada akses masuk. Konsentrasi RTH pribadi yang terdapat di areal belakang kawasan berupa taman buah yang cukup luas dan terdapat fasilitas tempat me-mancing. Hasil pengamatan menya-takan bahwa pada capaian sudah $300 \mathrm{~m}$, tidak ada fasilitas taman RT yang tersedia. Fasilitas umum yang besar adalah Masjid yang berada di tengah permukiman kompleks tersebut, namun justru tidak terpenuhi juga kebutuhan ruang hijaunya. Tidak dapat dipastikan apakah sejak awalnya tidak ada perencanaan matang untuk penempatan fasilitas umum-fasilitas sosial (termasuk tem-pat ibadah dan ruang pertemuan warga), sehingga dengan berjalannya waktu, maka berkembang pula kebutuhan-kebutu-han yang lain seperti pembangunan Masjid. Pada beberapa blok rumah yang ada, terdapat di ujung kavling, sisa lahan yang tidak digunakan atau masih belum digunakan. Kemungki-nan areal pasif itu sedianya direncanakan untuk ruang hijau pada sudutsudut jalan, namun oleh warga belum digunakan atau masih dibiarkan demikian adanya sehingga rumputrumput liar yang tumbuh tanpa ada fasiltas bermain anak-anak. Di samping itu, penggunaan lahan tiap kavling rumah, ada umumnya dihabiskan untuk bangunan dan sisa lahan menggunakan paving-block atau keramik.

b. Dari aspek ekologi (topografi-geografi), lokasi taman relatif pada permukaan yang sama seperti permukaan kavling rumah dan jalan, sehingga pencapaiannya tidak sulit atau relatif mudah dan tidak melelahkan. Lapangan Bumi Marina sebagai RTH pe-rumahan tersebut, idealnya menjadi penyeimbang ekologi lingkungan sekitar, baik dari kemampuan daya resap air ke dalam tanah dan sebagai ameliorasi iklim atau paru-paru kawasan Bumi Marina yang dapat membantu keseimbangan suhu sekitarnya. Tetapi pada kenyataannya. Lapangan tersebut hanya memiliki tiga buah pohon peneduh (Pohon Ketapang), sisanya adalah pohon jenis pengarah (Pohon Palem dan Glodokan Tiang) yang ditanam berselang-seling pada dua sisi lapangan. Jenis pohon pengarah yang banyak ditanami itu kurang berpotensi sebagai vegetasi mengkonversi karbon, maka lapangan Bumi Marina tidak memiliki peran dalam hal ameliorasi iklim kawasan perumahan.

c. Dari aspek estetika, lapangan Bumi Marina memberikan nilai estetika 
yang baik karena berada pada akses masuk kawasan sehingga menjadi 'areal penerimaan' yang baik. Elemen pelengkap lapangan yang dijejerkan di sisi jalan raya, seperti pohon palem dan lampu-lampu yang tinggi membuat lapangan jadi lebih tertata.

d. Dari aspek sosial, ekonomi dan budaya, lapangan Bumi Marina memberikan peluang bersosialisasi para penghuni kompleks bahkan dengan masyarakat di luar kompleks tetapi tidak untuk semua penghuni kompleks. Lapangan ini juga sebagai sarana pendukung kegiatan perekonomian deretan ruko, digunakan penjaja jajanan keliling berjualan pada jam sore dan malam hari. Hanya terdapat fasilitas bermain anak-anak.

\subsection{Implementasi arahan dan konsep redisain RTH Bumi Marina}

Setelah mengurai banyak aspek permasalahan, berikut ini implementasi arahan dan konsep redisain lapangan Bumi Marina pada Tabel 1 dan Gambar 3.

Setelah mempertimbangkan 4 aspek, berikut ini implementasi arahan dan konsep redisain taman RT/RW Bumi Marina pada Tabel 2 dan Gambar 4.

Tabel 1. Uraian situasi lapangan Bumi Marina

Kondisi lapangan saat ini (Gambar 3 atas)

Deretan tanaman Palem dan Glodokan tiang pada sisi jalan raya dan akses masuk

Fasilitas bermain anak di sudut.

Lampu taman sepanjang sisi luar

Tidak ada tempat duduk yang teduh

Parkir sembarangan di sisi lapangan.

Tidak ada areal untuk para difabel dan usia lanjut

\section{Kondisi redisain lapangan} (Gambar 3 bawah)

Mengganti tanaman peneduh potensial mengkonversi karbon, minimal 25 buah.

Menambah areal bermain anak. Penambahan bila perlu

Penambahan gazebo sebagai pembagi zona lapangan (tiga zona).

Penyediaan areal parkir dengan material yang beda. Menyediakan side-walk untuk para difabel dan usia lanjut untuk memiliki kenyamanan tersendiri bila menghabiskan waktu senggang di lapangan

Sumber: Hasil Analisa 


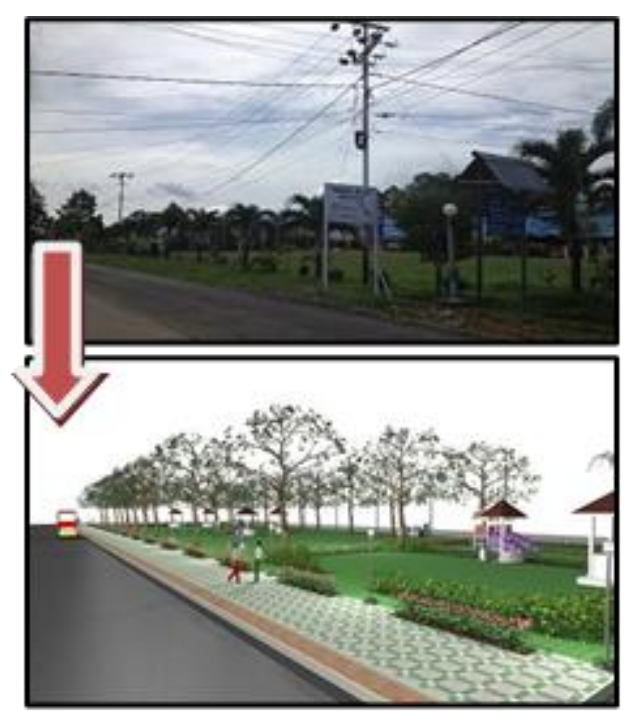

Gambar 3. Situasi awal (atas) dan situasi redisain lapangan (bawah).

Tabel 2. Uraian situasi lapangan Bumi Marina

$\begin{array}{cc}\begin{array}{c}\text { Kondisi lapangan saat ini } \\ \text { (Gambar 4. kiri) }\end{array} & \begin{array}{c}\text { Kondisi redisain lapangan } \\ \text { (Gambar 4. kanan) }\end{array}\end{array}$

Lahan kosong ditanami rumput ilalang. Menyediakan tempat duduk (para-para kayu) dengan tanaman merambat.

Sisi taman ditanami Pohon Glodokan tian Mengganti tanaman bambu hias sebagai Terkadang menjadi tempat kayu rongsokan. elemen dinding taman, karena baik untuk reduktor polutan.

Lahan kosong yang lain terkadang dipakai Menyediakan rak bunga dengan pot-pot anak-anak untuk bermain. kecil tanaman hidup.

Menyediakan fasilitas ayunan, alas rumput gajah mini, lampu dan tempat sampah pilah.

Sumber: Hasil Analisa

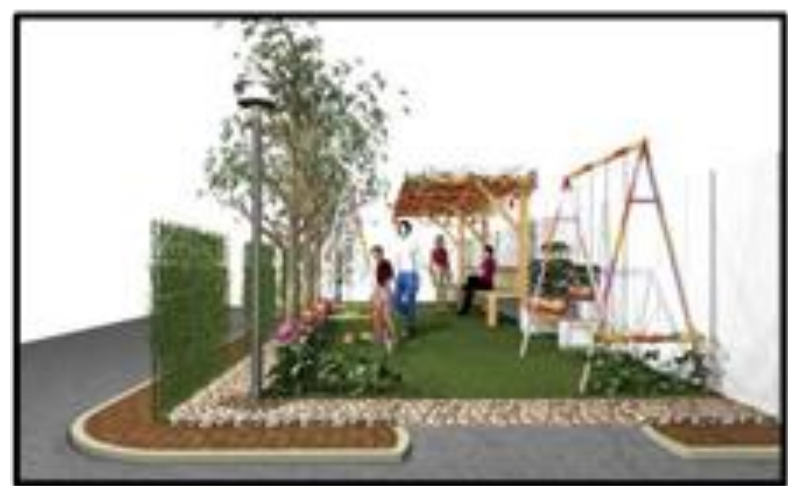

Gambar 4. Situasi awal taman RT/TW dari lahan kosong yang tidak dijadikan bagian dari RTH. 


\section{RTH Bandara Eduardo Osok, Sorong}

\subsection{Gambaran Kondisi Eksisting}

RTH Bandara Eduaro Osok, berada di pinggir jalan di depan kawasan bandara, tepatnya di luar pagar kawasan bandara. Bentuknya linear memanjang sejajar jalan raya. RTH ini akan dilewati orang yang keluar masuk kawasan bandara. Lahan RTH berbentuk linear memanjang di kiri kanan akses menuju bandara, dengan luas masing- masing \pm $1500 \mathrm{~m}^{2}$ untuk sisi kiri dan kanan. RTH ini masuk kategori Kawasan Hijau Binaan, dengan bentuk 'taman kota' yang menonjolkan nilai estetikanya memberi kesan pandang keindahan kota khususnya estetika yang mendukung keberadaan bandara Sorong sebagaimana Kota Sorong dikenal sebagai kota transit.

\subsection{Evaluasi Aspek Kelayakan RTH}

a. Dari aspek tata ruang (secara spasial) menempatkan taman pada sepanjang jalan raya yang menuju pintu masuk bandara Taman ini merupakan elemen estetika kota, seca-ra visual tidak terpisahkan dengan kawasan bandara, karena merupakan ruang penerimaan pada ak-ses menuju bandara. Kawasan bandara tersebut memiliki ruang terbuka hijau yang mendominasi karena areal penerbangan membutuhkan ruang terbuka yang luas. Dalam penataan ruang kota Sorong, hal ini sedianya sudah direncanakan karena RTH yang berada di depan kawasan bandara dimaknai sebagai RTH pembatas antara kota dan kawasan bandara. Sebelumnya, lahan tersebut adalah tanah kosong belum ditata. Sehingga masih berkesan liar. Penyediaan RTH yang bertahap dan tidak berlanjut, membuat taman di kiri dan kanan masih belum tuntas.

b. Dari aspek ekologi (topografi-geografi), lokasi taman relatif lebih rendah dari jalan, sehingga memudahkan penglihatan dan pencapaian dari arah sekitarnya. Sedianya RTH tersebut dapat dijadikan 'paru-paru' kawasan untuk skala kecil. karena jalan raya yang berada di sisi depannya, cukup banyak kendaraan sehingga sudah terasa panas, dengan kondisi kurang pola hijau di sepanjang jalan

c. Dari aspek estetika taman RTH ini seharusnya dapat memberikan manfaat estetika yang baik, tetapi belum maksimal karena pembangunan fisik tamannnya tidak berlanjut (terbengkalai). Taman ini belum mendapatkan perhatian pengelolaan dan perawatan yang semestinya, karena sebagian pohon yang sudah ditanam pada tahap-1 sudah tidak ada lagi (hilang). Dengan kondisi demikian, taman ini memberi kesan tidak bertuan; maka sebagian masyarakat sekitar memanfaatkan ruang kosong ini sebagai tempat banner kampanye dan tempat parkir mobil atau angkutan mobil pada jam istirahat.

d. Dari aspek sosial, ekonomi dan budaya, tidak memberi dampak yang signifikan karena kenyataannya hanya digunakan sebagai tempat parkir dan pajangan banner kampanye. Taman tidak memberikan estetika yang mengangkat muatan lokal budaya setempat. Tidak terjadi kegiatan ekonomi yang berlangsung di taman. 


\subsection{Implementasi arahan dan konsep redisain RTH depan bandara}

Setelah mempertimbangkan 4 aspek, berikut ini implementasi arahan dan konsep redisain taman RT/RW Bumi Marina pada Tabel 3.1 dan Gambar 3.1. Dari lima RTH yang diamati dan dievaluasi dalam penelitian ini, ada tiga RTH yang belum memenuhi fungsi ekologis secara maksimal yaitu RTH Taman Isak Kijne, Taman Perumahan Bumi Marina dan RTH Bandara Eduardo Osok (RTH-1, 2 dan 3). Hasil evaluasi telah memberikan sebuah gambaran kondisi RTH saat ini yaitu $60 \%$ RTH yang ada perlu dilakukan pembenahan ulang (redisain) untuk mengembalikan fungsi ekologisnya. Dua kasus RTH yang lain (Perkantoran Bupati-Waisai dan Taman Perkantoran Arfai) mendapatkan apresiasi yang positif dari para responden dan hasil evaluasi menunjukkan bahwa kedua RTH dimaksud sudah memenuhi fungsi ekologis secara maksimal. Tetapi pada RTH perkantoran arfai (studi ke-5) hanya perlu penambahan elemen estetika untuk mempertegas eksistensi dan wajah RTH karena pertimbangan sudut pandang yang strategis.

Seperti yang tercantum dalam Pedoman Penyediaan RTH yang diterbitkan oleh Kementerian Pekerjaan Umum, bahwa perlunya menggunakan vegetasi endemik lokal, sebagai upaya untuk pelestarian tanaman khas daerah sendiri selain sebagai upaya untuk mem- perkenalkan tanaman khas daerah (edukatif dan introduktif). Tanaman endemik Papua sebaiknya selalu disertakan dalam pemilihan vegetasi penyediaan RTH untuk menambah nilai estetika-budaya lokal. Sebagai contoh, Pohon Matoa yang diklaim berasal dari Papua, memiliki potensi untuk konversi karbon, maka sangat baik untuk menggunakan tanaman tersebut sebagai salah satu unsur vegetasi lokal dalam penyediaan RTH. Pohon Golodokan Tiang yang diklaim berasal dari India, ternyata sangat cocok tumbuh di daerah Tanah Papua, de-ngan kondisi tanah mengandung karang. Pohon Glodokan Tiang cocok sebagai pembatas pada RTH, ditanam rapat berderet sebagai penahan angin. Cemara Papua sebagai tanaman hias, juga tidak kalah bagusnya dengan cemara jenis lain, karena berkarakter evergreen dan mudah perawatannya. Bunga Api Irian yang bernilai estetis sebagai tanaman merambat untuk naungan (shelter), Tanaman Zodia, yang protektif untuk mengusir nyamuk dapat melengkapi unsur vegetasi taman RT/RW tempat bermain anak-anak. Bunga Kantong Semar Papua yang indah dan Tanaman Buah Merah, Sagu Papua, tanaman endemik Papua yang harus dikonservasi, beragam anggrek Papua dapat menjadi khazanah taman RTH untuk agro wisata, Mahkota Dewa juga indah sebagai pelengkap taman dan sebagainya.

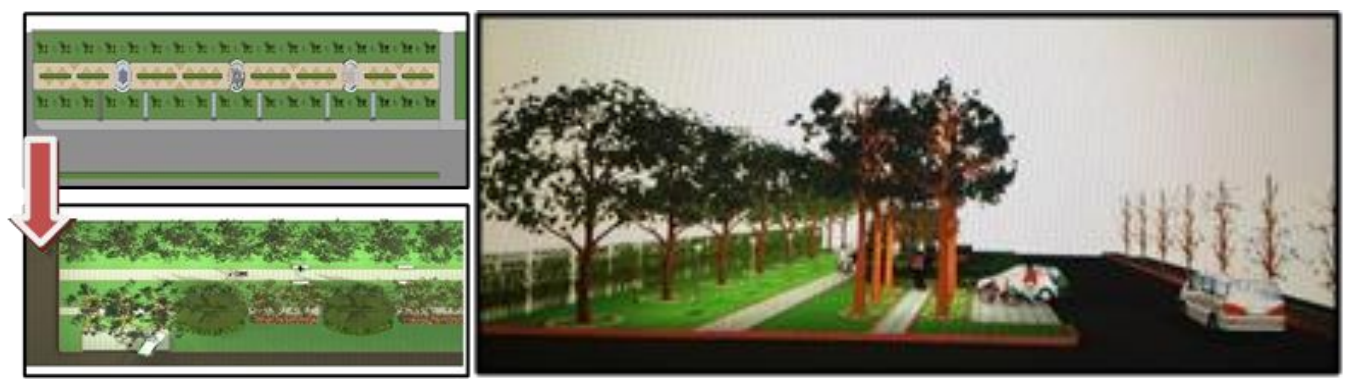

Gambar 5. Situasi awal (kiri atas), situasi redisain taman sabuk-hijau (kiri bawah) dan perspektif situasi (kanan). 
Tabel 3. Uraian situasi awal dan redisain RTH depan kawasan bandara

\begin{tabular}{|c|c|}
\hline Kondisi Awal & Kondisi Redesain \\
\hline Pohon cemara sudah tidak ada & $\begin{array}{l}\text { Menempatkan vegetasi sebagai dinding } \\
\text { taman(pohon Bambu dan Glodokan } \\
\text { Tiang yang berjejer). }\end{array}$ \\
\hline \multirow[t]{2}{*}{$\begin{array}{l}\text { Pot-pot bunga hanya ditumbuhi rumput } \\
\text { liars }\end{array}$} & $\begin{array}{l}\text { Pemberian pohon Mahoni sebagai } \\
\text { peneduh di areal parkir yang terbatas 5- }\end{array}$ \\
\hline & 6 mobil. \\
\hline $\begin{array}{l}\text { Pohon jenis peneduh yang ada sekarang } \\
\text { adalah pohon Ketapang dan beberapa } \\
\text { buah Mahoni }\end{array}$ & $\begin{array}{l}\text { Pohon Dadap merah diatur bergandengan } \\
\text { dengan cemara untuk dinamis nya } \\
\text { estetika taman, Pohon Dadap juga dapat } \\
\text { mengun-dang datangnya burung-burung } \\
\text { kecil ke taman sehingga menambah } \\
\text { suasana riang di taman }\end{array}$ \\
\hline $\begin{array}{l}\text { Tidak ada lampu taman kecuali } \\
\text { penenerangan jalan }\end{array}$ & $\begin{array}{l}\text { Pohon peneduh jenis penyerap kabon } \\
\text { ditambahkan sepanjang side-walk dalam } \\
\text { taman }\end{array}$ \\
\hline $\begin{array}{l}\text { Tempat parkir kendaraan di jam istirahat } \\
\text { (siang-sore). }\end{array}$ & $\begin{array}{l}\text { Elemen tanaman pangkas berbentuk pe- } \\
\text { sawat akan mempertegas kebedaraan ka- } \\
\text { wasan bandara di belakang taman, }\end{array}$ \\
\hline Tidak ada tempat sampah & $\begin{array}{l}\text { Pemberian asesoris taman seperti bangku, } \\
\text { lampu taman dan tempat sampah yang } \\
\text { edukatif (pola pemisahan jenis sampah). }\end{array}$ \\
\hline
\end{tabular}

Sumber: Hasil Analisa

\section{KESIMPULAN}

Sebagian besar RTH yang dievaluasi, belum mencapai fungsi ekologis yang maksimal atau belum menjamin upaya konversi karbon terjadi di dalamnya. Maka dalam redisain RTH dilakukan dengan point- point berikut:

a. Penentuan tipologi RTH pembenahan lay-out,

b. Pembenahan jenis material softlandscaping (unsur vegetasi) dan hardlandscaping (unsur non-vegetasi),

c. Prioritas penggunaan vegetasi/pohon peneduh yang berpotensi mengkonversi karbon dan mengupayakan penggunaan tanaman endemik lokal sebagai penyempurna aspek estetika dan budaya setempat,

d. Menjadikan RTH sebagai paru-paru kawasan.

Berdasarkan hasil penelitian, beberapa hal dapat disarankan sebagai berikut:

1. Perlunya diadakan sosialisasi komunikasi yang efektif tentang penyediaan RTH, antara pemerintah terhadap masyarakat dan swasta pelaku jasa konstruksi. Sehingga semua pihak memiliki kesadaran pentingnya RTH.

2. Perlunya konsistensi perencanaan dan pengawasan penyediaan RTH untuk menjaga keseimbangan ekologi dalam setiap perjalanan pembangunan, melakukan pembenahan RTH secara bersinergi antar pemerintah, swasta dan masyarakat.

3. Perlunya dilakukan pengkajian lagi untuk mengukur capaian fungsi eko- 
logis RTH perkotaan yang telah terbangun, misalnya mengukur penyerapan Karbondioksida tiap RTH.

4. Perlunya penelitian lebih lanjut untuk penentuan tipologi RTH pada rencana green-mapping tiap Kabupaten/Kota Provinsi Papua Barat yang kemudian dapat dijadikan sebagai kajian akademis pengusulan dan penyusunan Peraturan Daerah tentang RTH.

5. Perlunya penelitian lebih lanjut tentang potensi vegetasi endemik Papua dalam penyediaan RTH.

\section{DAFTAR PUSTAKA}

Adisasmito W, (2008). Rancangan Peraturan Daerah Kota Cilegon Tentang Ruang Terbuka Hijau Kota Cilegon. Naskah Akademik. Fakultas Kesehatan Masyarakat. Universitas Indonesia.

Anonim. (2002). Undang-Undang Republik Indonesia No. 28 Tahun 2002 Tentang Bangunan Gedung.

Anonim. (2005). Pengembangan Sistem RTH di Perkotaan. Makalah Lokakarya. Laboratorium Perencanaan Lanskap Departemen Arsitektur Lanskap. Fakultas Pertanian. Institute Pertanian Bogor.

Anonim. (2007). Undang-Undang Republik Indonesia No.26 Tahun 2007 Tentang Penataan Ruang.

Anonim. (2008). Peraturan Menteri Pekerjaan Umum No.5/PRT/M/ 2008 Tentang Pedoman Penyediaan dan Pemanfaatan Ruang Terbuka Hijau di Kawasan Perkotaan. Kementerian Pekerjaan Umum: Jakarta.
Anonim. (2012). Creating Space for Better Life. Departemen of Architecture Faculty of Civil Enggineering \& Planning. Proceeding Book. Universitas Trisakti: Jakarta, [pg 204, 301, 387, 409, 423, 449,455, 473,527, 567,711].

Amirin, TM. (2009). Penelitian Eksploratori (eksploratif), diunggah tanggal 29 Agustus 2009. http://tatangmanguny.wordpress. com).[pengambilan data tanggal 20 Februari 2014].

Arman, I. (2014). Komposisi dan Timbulan Sampah Serta Produksi Emisi Gas Rumah Kaca Limbah Padat di Kabupaten Manokwari. Tesis. Program Pascasarjana Universitas Negeri Papua.

Arsyad, S. 2010. Konservasi Tanah dan Air. Institute Pertanian Bogor Press: Bogor

Dahlan, EN. 2008. Tanaman Penyerap Karbondioksida, Harian Jurnal Asia pada 07 Oktober 2014. http://jurnalasia.com/2014/10/07 /tanaman-penyerap-karbondioksida. [pengambilan artikel tanggal 23 November 2014].

Dewi EP, 2009. Analisis Ruang Terbuka Publik Bersejarah Dalam Rangka Revitalisasi Kota Tua Jakarta. Tesis. Program Pascasarjana Institute Pertanian Bogor.

Direktorat Penataan Bangunan dan Lingkungan 2012. Menata Ruang Terbuka Hijau di Kawasan Perkotaan. Direktorat Jenderal Cipta Karya Departemen Pekerjaan Umum. Jakarta. http://leumburkuring.files.wordp ress.com/2012/05/menataruang- 
terbuka-hijau-di-kawasan-perkotaan.pdf. [pengambilan data tanggal 2 April 2014].

Dwi D, 2011. Model Pengelolaan Ruang Terbuka Hijau Sebagai Daerah Resapan di Wilayah DKI Jakarta. Tesis. Program Pascasarjana Institute Pertanian Bogor.

Hastuti E. dan Utami T, 2008. Potensi Ruang Terbuka Hijau Dalam Penyerapan $\mathrm{CO} 2$ di Permukiman. Naskah. Pusat Penelitian Pembangunan Permukiman. Bandung.

Kusminingrum N, 2008. Potensi Tanaman Dalam Menyerap $\mathrm{CO} 2$ dan CO untuk Mengurangi Dampak Pemanansan Global. Naskah. Pusat Litbang Jalan dan Jembatan. Bandung.

Moniaga IL, 2008. Studi Ruang Terbuka Hijau Kota Manado Dengan Pendekatan Sistemik. Tesis. Program Pascasarjana Institute Pertanian Bogor.

Nirwono Y, 2011. RTH 30\%! Resolusi (Kota) Hijau. PT. Gramedia Pustaka Utama:Jakarta.

Radnawati D, 2005. Evaluasi RTH Kota Depok Sebagai Kawasan Konversi Air Menggunakan Data Satelit Temporal. Tesis. Program Pascasarjana Institute Pertanian Bogor.

Sihombing R, 2012. Kajian Kebutuhan Jalur Hijau Sebagai Penyerap Emisi Karbondioksida Kendaraan Bermotor Disepanjang Jalan Arteri Kota Manokwari. Tesis Program Pascasarjana Universitas Negeri Papua.
Sukandarrumidi 2002. Metodologi Penelitian. Gajah Mada University Press: Yogyakarta. Tim IPB 1993. dikutip oleh Mukafi A, 2013. Tingkat Ketersediaan Ruang Terbuka Hijau di Kota Kudus. Skripsi. Program Studi Pendidikan Teknik Bangunan. Universitas Negeri Semarang. 